\title{
Petrographic and geochemical investigation of a stone adze made of nephrite from the Balatonőszöd - Temetői dülő site (Hungary), with a review of the nephrite occurrences in Europe (especially in Switzerland and in the Bohemian Massif)
}

\author{
Bálint PÉTERDI ${ }^{1, *}$, György SZAKMÁNY², Katalin JUDIK ${ }^{3}$, Gábor DOBOSI ${ }^{3}$, Zsolt KASZTOVSZKY ${ }^{4}$, \\ Veronika SZILÁGYI ${ }^{4}$, Boglárka MARÓTI ${ }^{4}$, Zsolt BENDÖ ${ }^{2}$ and Grzegorz $\mathrm{GIL}^{5}$ \\ 1 Geological and Geophysical Institute of Hungary, Department of Geological and Geophysical Collections, H-1143, \\ Stefánia út 14, Budapest, Hungary \\ 2 Eötvös Loránd University, Faculty of Science, Institute of Geography and Earth Sciences, Department of Petrology and \\ Geochemistry, H-1117, Pázmány Péter sétány 1/C, Budapest, Hungary \\ 3 Hungarian Academy of Sciences, Research Centre for Astronomy and Earth Sciences, Institute for Geological and Geo- \\ chemical Research, H-1112, Budaörsi út 45, Budapest, Hungary \\ 4 Hungarian Academy of Sciences, Centre for Energy Research, Nuclear Analysis and Radiography Department, H-1121, \\ Konkoly Thege Miklós út 29-33, Budapest, Hungary \\ 5 University of Wrocław, Institute of Geological Sciences, PI. Maksa Borna 9, 50-205 Wrocław, Poland
}

Péterdi B., Szakmány G., Judik K., Dobosi G., Kasztovszky Z., Szilágyi V., Maróti B., Bendő Z. and Gil G. (2014) Petrographic and geochemical investigation of a stone adze made of nephrite from the Balatonőszöd - Temetői dűlő site (Hungary), with a review of the nephrite occurrences in Europe (especially in Switzerland and in the Bohemian Massif). Geological Quarterly, 58 (1): 181-192, doi: 10.7306/gq.1146

The present study reports on results of petrographic and geochemical analyses on a stone adze from the archaeological Balatonőszöd - Temetői dűlő site (SW-Hungary, on the southern side of Lake Balaton). This is the largest excavated site of the Baden Culture in Hungary (more than 200,000 $\mathrm{m}^{2}$ ) and has the longest continuous settlement history. At the site, features of the Balaton-Lasinja Culture (Middle Copper Age) and the Boleraz Culture have also been found. Altogether 500 stone artefacts were found and registered. The present study reports on the results of the investigation of a unique nephrite adze, found on the site. This adze is the first nephrite artefact with an established archaeological context in Hungarian prehistory. By applying detailed petrographic, geochemical and petrophysical methods as well as comparing with published data we have located the origin of the raw material of this nephrite adze. Its most probable source is the northern part of the Bohemian Massif, Lower Silesia, a geological site near Jordanów (Poland).

Key words: archaeometry, polished stone tools, Baden Culture, nephrite, Balatonőszöd (Hungary), Jordanów (Poland).

\section{ARCHAEOLOGICAL BACKGROUND AIM OF THE STUDY}

Balatonőszöd - Temetöi dülö is the largest excavated and longest-lived archaeological site of the Late Copper Age Baden Culture in Hungary. The total territory of the excavated and the connected registered site is more than $200,000 \mathrm{~m}^{2}$ (Fig. 1). At the site, features of the Balaton-Lasinja Culture and the Boleraz Culture have also been found. Some features of the two cultures occurred together (mixed) though no traces of any later digging in or disturbance was observable in the section (Horváth et al., 2006; Horváth, 2010).

* Corresponding author, e-mail: peterdi.balint@gmail.com

Received: October 15, 2013; accepted: December 18, 2013; first published online: January 31, 2014
Altogether 500 stone artefacts turned up. Their archaeological classification was carried out by Tünde Horváth.

Most of the stone tools investigated are fragments of grinding stones (on a few of them, traces of mineral paint were observed), grinders, polishers, stone axe pre-forms and a few axes. Objects whose function is not known, boulders of raw material and cores of shaft-hole axes were also found. Almost all of the polished stone artefacts (axes) are made of basalt, the source of the basalt raw material most probably being the basaltic rocks of the nearby volcanoes of the Balaton Highland [Hegyestü, Haláp, Uzsa, and Halyagoshegy (Diszel)] (Péterdi et al., 2011). There is only one stone adze made of nephrite in the set studied. Since we do not know any nephrite source in the Carpathian Basin (and its surroundings), the raw material (or, better to say, the stone adze itself) must have originated from a distant source.

Its pleasing aesthetic appearance and its toughness - ensured by the compact fabric consisting of interweaving and interlocking thin, fine amphibole fibres - makes nephrite an excel- 


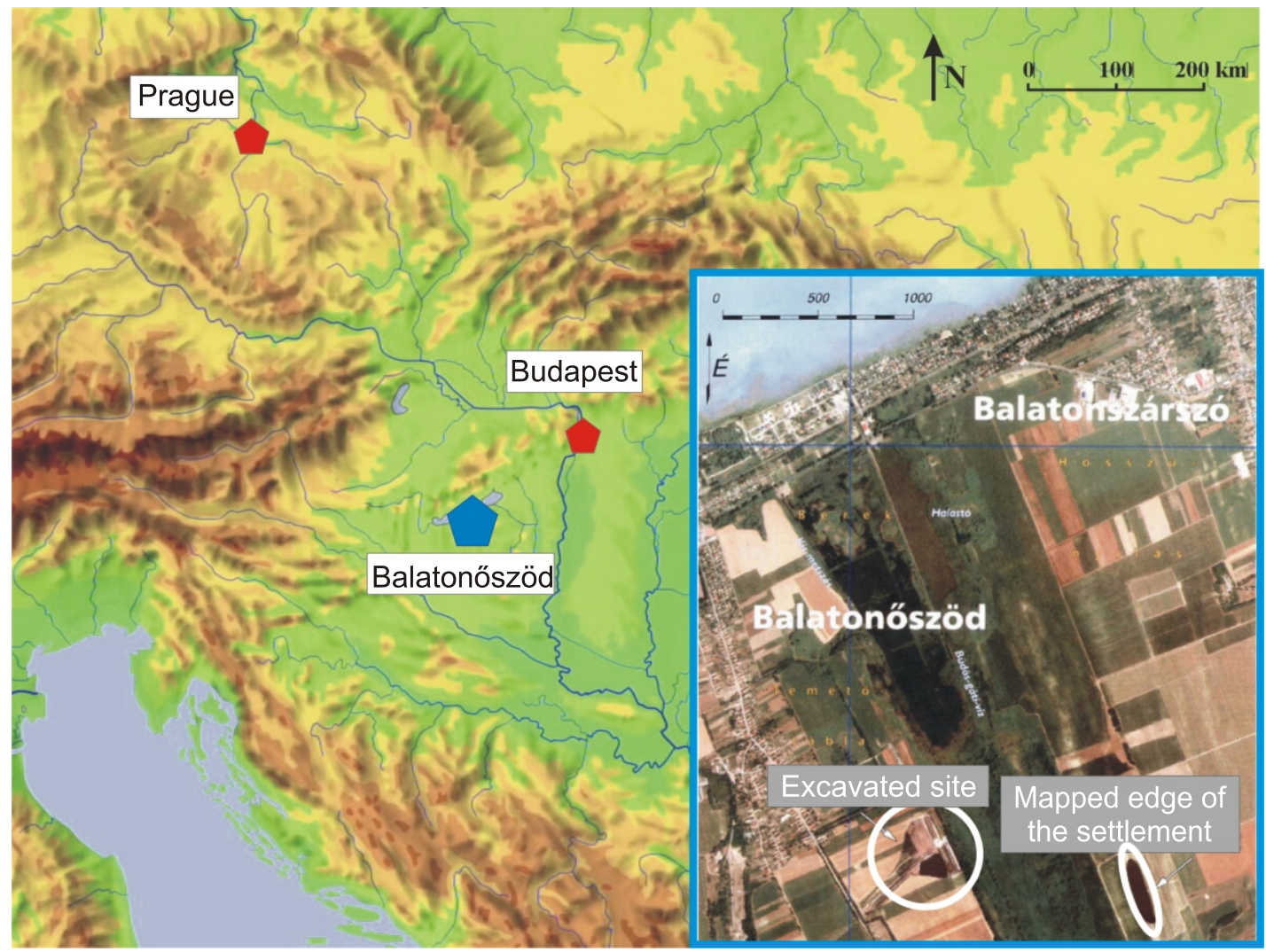

Fig. 1. Location of the Balatonőszöd - Temetöi dülö site

lent raw material for polished stone tools, and so it became a widespread raw material all over Europe in the Neolithic and the Bronze Age; however, it was not used (as raw material) in large quantities because of the small size and limited occurrence of the nephrite bodies.

Nephrite is present rarely among archaeological finds in Hungary and it is known exclusively from Transdanubian sites, primarily in the material of old surface collections such as the Miháldy Collection of Veszprém (Szakmány et al., 2001) and the Ebenhöch Collection of the Hungarian National Museum (Friedel, 2008; Friedel et al., 2008). The archaeological finds curated in the above collections cannot be identified according to either age or culture because of a lack of information concerning their provenance (Horváth, 2001). Therefore, the Balatonőszöd - Temetői dülő nephrite adze is the first authentic Hungarian find with reliable archaeological context dating back to prehistory.

The general aim of our study is the detailed petrographic and geochemical examination of the stone tools found at the Balatonőszöd - Temetői dűlő archaeological site, and locating the origin of the raw materials. Here we focus on this unique nephrite adze.

\section{METHODS}

The material of the stone artefacts found at Balatonőszöd Temetői dülő was classified according to raw material; we divided them into groups on the basis of macroscopic investigation. Thin sections were made of samples of a given group (from either fragments or of pieces having less value from an archaeological point of view) to carry out detailed petrographic microscopic analyses. Results of the microscopic examinations (mineral composition, fabric) were completed with geochemical [bulk-rock chemistry (PGAA), mineral chemistry (EPMA, SEM-EDX)] and petrophysical examinations (magnetic susceptibility; Appendix $\left.1^{*}\right)$.

Recently found nephrite samples from possible sources were analysed by PGAA (Appendix 1), and the results were compared to published data. The large amount of data was represented diagramatically.

Prompt-gamma activation analyses (PGAA) were performed using the $10^{8} \mathrm{~cm}^{-1} \mathrm{~s}^{-1}$ intensity cold neutron beam of the Budapest Research Reactor at the Hungarian Academy of Sciences Institute of Isotopes (now the HAS Centre for Energy Research). A precisely calibrated HPGe-BGO detector system

\footnotetext{
* Supplementary data associated with this article can be found, in the online version, at doi: 10.7306/gq.1146
} 

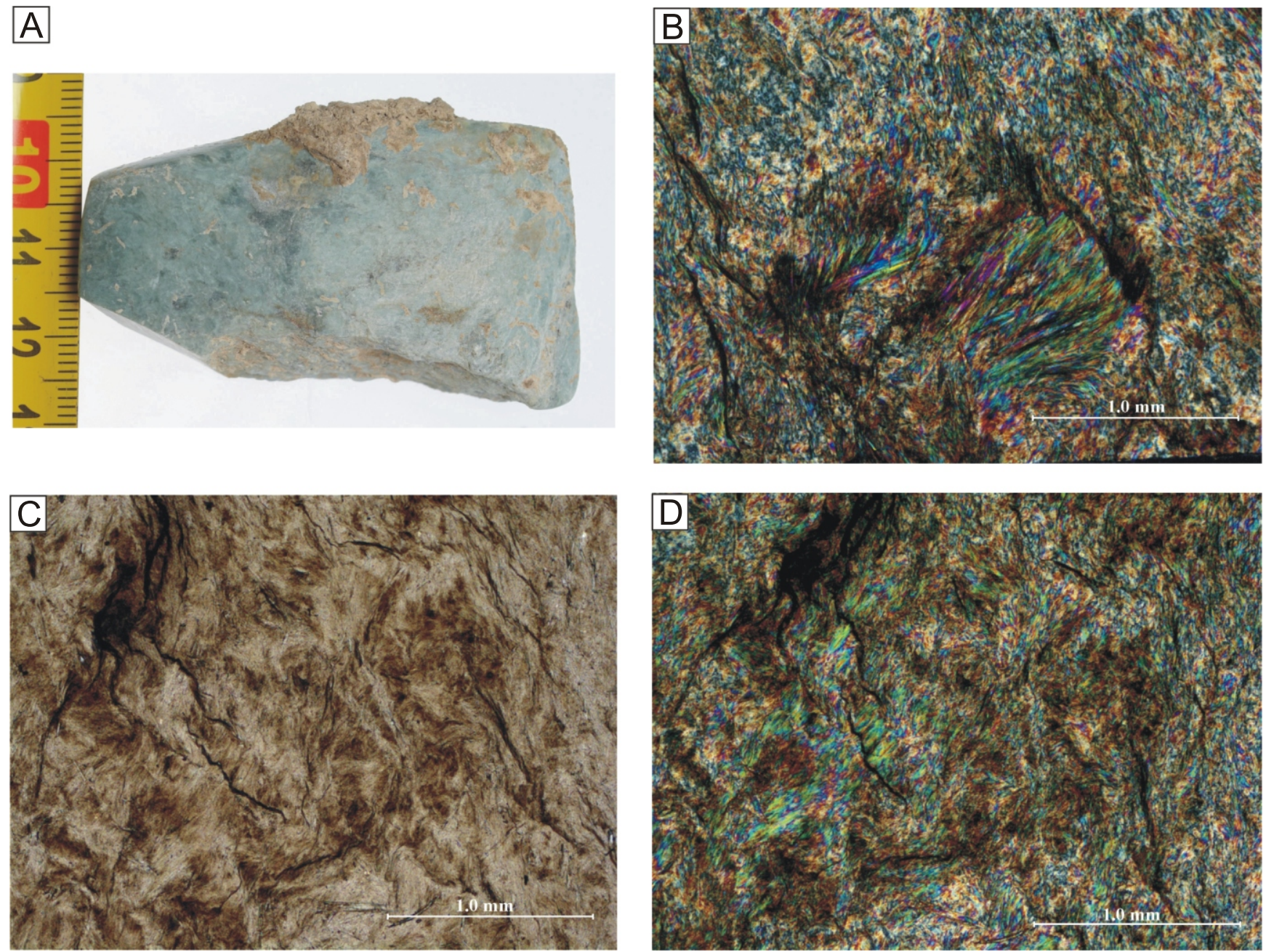

Fig. 2A - photo of the nephrite adze; B - photomicrograph (crossed polars) of rock texture; C - photomicrograph (plane polarized light) of rock texture; D - photomicrograph (crossed polars) of rock texture

was used for detection of prompt gamma photons. The experimental set-up was described by Szentmiklósi et al. (2010). Quantitative determination of most major and some trace elements was made, based on our PGAA library (Révay, 2009).

Mineral-chemical examinations of the thin section (SEM, EPMA) were performed at the Institue for Geochemical Research, HAS (now the HAS Research Centre for Astronomy and Earth Sciences, Institute for Geological and Geochemical Research; JEOL Superprobe 733 type equipment, with an Oxford Instruments INCA Energy 200 energy dispersive spectrometer; $15 \mathrm{kV}$ accelerating potential, 4nA sample current).

Non-destructive mineral-chemical examination of the surface of the adze (SEM-EDX) was performed with the "original surface investigation method" (Bendő et al., 2012) at the Department of Petrology and Geochemistry of the Institute of Geography and Earth Sciences of the Eötvös University (ELTE). The instrument is an AMRAY 1830 type SEM, with an EDAX $P V 9800$ energy dispersive spectrometer. Conditions of analyses: accelerating potential: $20 \mathrm{kV}$; beam current: $1 \mathrm{nA}$; focussed electron beam (diameter: $\sim 50 \mathrm{~nm}$ ). Fairly large samples can be placed into the sample chamber of this electron microscope so the stone implements could be placed into the sample chamber without intrusive preparation.

Magnetic susceptibility (MS) examinations were performed at the Department of Petrology and Geochemistry of Eötvös
University (KT-5 type Kappameter; for correction methods see Bradák et al., 2005, 2009).

\section{RESULTS - PETROGRAPHY AND MINERAL CHEMISTRY (EPMA)}

\section{MACROSCOPIC FEATURES}

The adze is made of very fine-grained metamorphic rock; its colour is light green, but in some places it shows a darker green or pale blue hue (Fig. 2A). Moderately large crystals are not visible either to the unaided eye or using a hand lens. The polished surfaces have a silky lustre. Here and there fibrous structure shows: the wavering fibres are white or extremely light green. Patches of red-brown hue show on the surface.

\section{MICROSCOPIC FEATURES}

The rock is monomineralic; very fine fibrous amphibole constitutes the mass of the rock (Fig. 2B-D); minute (50-100 $\mu \mathrm{m}$ ), idioblastic amphibole crystals are also present. The idioblastic crystals are spread unoriented; they also appear in the cross-section perpendicular to the C-axis (Fig. $3 \mathrm{~A}$ ) and parallel 

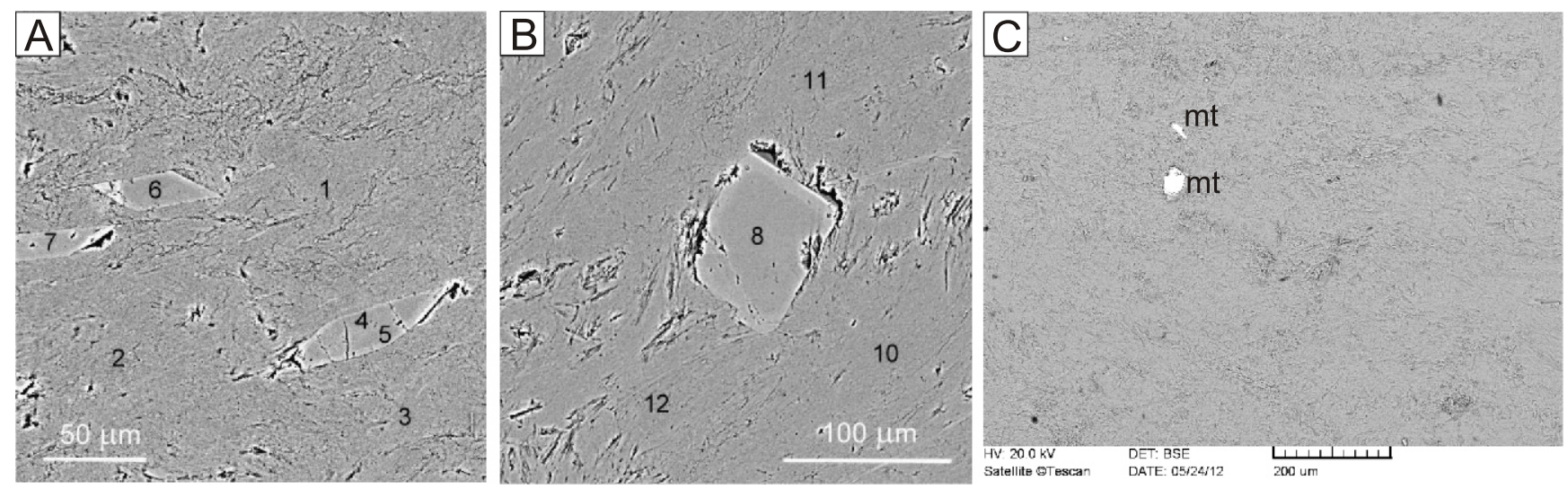

Fig. 3A - SEM-photomicrograph (thin section) of idioblastic tremolite crystals in tremolite matrix; B - SEM-photomicrograph (thin section) of idioblastic tremolite crystals in tremolite matrix; C - SEM-photomicrograph (surface method) of magnetite crystals in tremolite matrix

Numbers - EPMA measuring points; $m t$ - magnetite

with (010) (Fig. 3B). The fibres often waver here and form a fan-shaped pattern there (Fig. 2B); elsewhere they appear as tangled masses lacking orientation (Fig. 2C, D). Microanalyses show, that the amphibole fibres and idioblastic crystals do not differ much in composition; the amphibole is tremolite throughout, with $\mathrm{Si}$ apfu (atoms per formula unit) 7.9-8.0 and $\mathrm{Mg} /\left(\mathrm{Mg}+\mathrm{Fe}^{2+}\right)$ from 0.90 to 0.95 (Leake et al., 1997; Appendix 1 and Fig. 4).

Using the "original surface investigation method" we could not see any differences in texture and the amphiboles analysed on the surface of the adze show data that accords with the amphibole crystals measured in thin section [only the Mg-content shows a minor $(<2 \%)$ difference (Appendix 1$)$ that may result from the difference in analysis method (WDS vs. EDS)]. There are some relatively large $(20-200 \mu \mathrm{m})$ magnetite crystals in the red-brown patches on the surface (Fig. $3 \mathrm{C}$ ). In all probability these patches derived from the completely limonitization or hematitization of the magnetite crystals. It must be pointed out

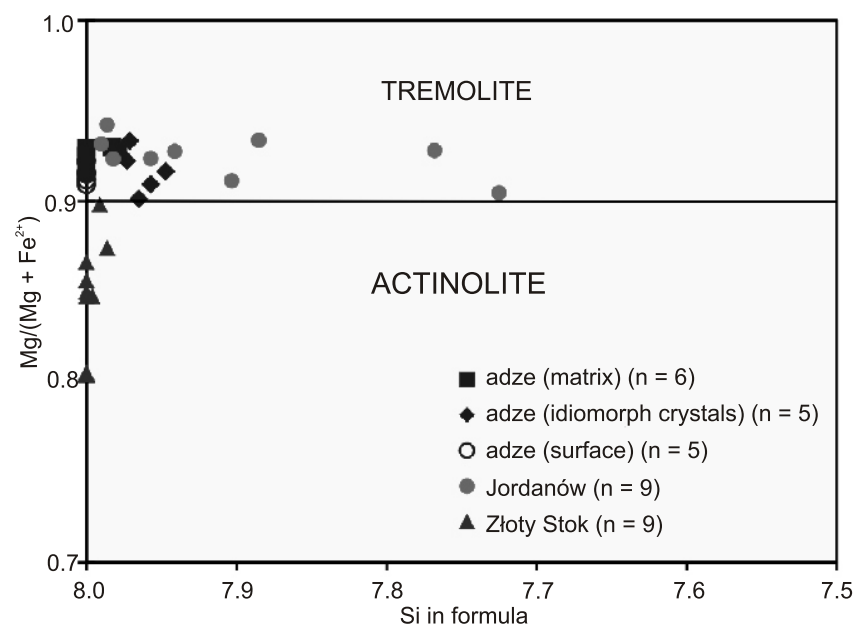

Fig. 4. Comparison of amphiboles from the Balatonőszöd Temetöi dülő site nephrite adze (performed by means of electron microprobe), with amphiboles from Jordanów and Złoty Stok nephrite deposits in Poland; diagram modified after Leake et al. (1997), Jordanów and Złoty Stok nephrites after Gil (2013) that magnetite crystals were absent in thin section (taken from the inside of the adze).

\section{BULK ROCK CHEMISTRY (PGAA) AND MAGNETIC SUSCEPTIBILITY (MS)}

Comparative PGAA studies on several types of rock occurring as raw material of archaeological finds have been made recently, with a dual purpose: to obtain chemical analyses of the raw material of archaeological finds non-destructively and to set up a data-base from the results of the analyses (Szakmány and Kasztovszky, 2004; Szakmány et al., 2011).

The composition of the nephrite adze found at Balatonőszöd - Temetői dülő is very much like that of the nephrite adze in the Ebenhöch Collection of the Hungarian National Museum (Friedel, 2008; Friedel et al., 2008); the only nephrite artefact in Hungary that had ever been examined by PGAA before. The characteristics of the raw material of both adzes are: the high silicon, magnesium and calcium, while low alumina, sodium, potassium and titanium contents. The composition of the whole rock is practically identical with that of individual amphibole crystals (based on EPMA and PGAA measurements; Appendix 1); the difference appears only in the higher iron-content probably caused by the red-brown, ferrous discolouration that is scattered on the surface of the rock.

The real MS value of the rock is low: $0.13^{\mathrm{x}} 10^{-3} \mathrm{SI}$ units, that is congruent with the values measured on the nephrite polished stone-tools both in the Miháldy Collection $\left(0.09-0.52^{\mathrm{x}} 10^{-3} \mathrm{SI}\right.$ units; Bradák et al., 2005) and the Ebenhöch Collection $\left(0.1-0.7^{\times} 10^{-3} \mathrm{SI}\right.$ units; Friedel, 2008; Friedel et al., 2008). The necessary corrections were calculated using the formula published by Bradák et al. (2005, 2009).

\section{POSSIBLE SOURCE REGIONS}

According to their formation, nephrites can be classified into two groups: one is formed by contact metasomatism between intermediate-acidic (e.g., granodiorite, tonalite) intrusions and dolomitic marbles (dolomite-related deposits, D-type), the other is formed by contact metasomatism between serpentinite and 


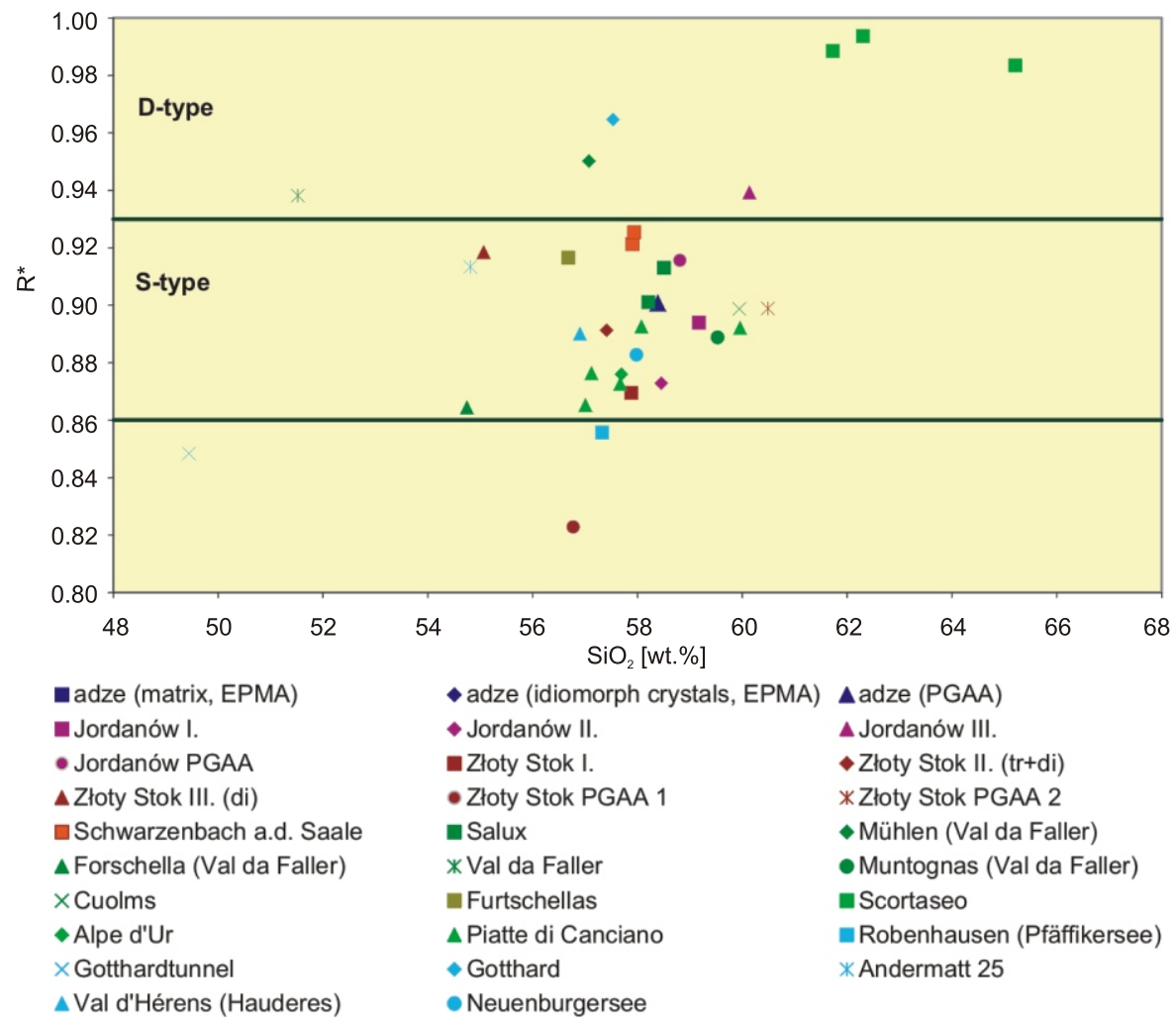

Fig. 5. Bulk-rock chemistry of the nephrite adze and nephrite samples from various geological sites: $\mathrm{R}^{*} \mathrm{Mg} /\left(\mathrm{Mg}+\mathrm{Fe}^{\mathrm{t}}\right)$ as a function of $\mathrm{SiO}_{2}$-content (wt.\%)

magmatic bodies (serpentinite-related deposits, S-type; Zhang et al., 2011).

There is a significant difference in chemical composition between the two types. The difference can be best expressed by the $\mathrm{Mg}^{2+} /\left(\mathrm{Mg}^{2+}+\mathrm{Fe}^{2+(3+)}\right)$ mol-ratio: i.e., D-type nephrites have 0.930-1 and S-type nephrites 0.860-0.930 (Zhang et al., 2011). In the case of the Balatonőszöd - Temetői dülö site nephrite adze, this value is 0.901 (Appendix 1 and Fig. 5), therefore the raw material examined is S-type, consequently it belongs among the serpentinized ultrabasic rocks.

Geological occurrences of nephrite are fairly rare in Europe. Known occurrences are the following: the Alps (Switzerland, Italy, France, Germany and Austria), the Apennines, the Harz Mts. and Scandinavia; also in the metamorphosed basic and ultrabasic complexes of the boundaries of the Bohemian Massif. Nephrite occurs among glacial erratics carried by ice from Scandinavia to Rügen Island, and in the environs of Potsdam and Leipzig (Gunia, 2000).

The so-called "Mur Nockerls" - nephrite-gravels, nephrite-boulders originating from the alluvium of the small stream Mur between Leoben and Graz - also deserve mention. The Mur flows into the Drava so it is nearer the Carpathian Basin than the other known provenances. Along its upper course (before it is breaking through the Glein Alm) several serpentinized rock masses occur, but the parent material of the nephrite-gravels is as yet unknown (Giess, 2005).

Since a significant number of polished tools made of nephrite have been found on the Balkan Peninsula a raw material source (of nephrite) has been suggested to be there by archae- ologists. However, the potential geological source has not yet been found (Kostov, 2005).

The identification of the provenance for the Balatonöszöd item is rendered more difficult because too many "green-coloured" rocks have been named nephrite in the past. The majority of these "green-coloured" rocks do not fit the concept of nephrite as understood petrographically today; the nomenclature of amphibole-types has changed, certain types of amphibole are known under several, different designations (i.e. in earlier literature "grammatite" and even "hornblende" are mentioned rather than tremolite or actinolite). In addition to comparison of the mineral composition and fabric, comparison of the results of chemical analyses available from certain provenances and the results of analyses of finds may offer support.

Monomineralic amphibole rocks $(100 \%$ tremolite, containing tremolite crystals among the tremolite fibres) similar to the Balatonőszöd - Temetői dülő nephrite cannot be found in Liguria (Italy) according to D'Amico et al. (2003). The most probable provenance of such nephrite finds in Italy might be Graubünden (Grisons) Canton in Switzerland (D'Amico et al., 2003).

The above-mentioned "Mur Nockerls" also belong to the tremolite-nephrites (Giess, 2005), but detailed descriptions or analyses are not available.

Data available from the two probable source areas consists of descriptions and survey data and concerns mineral, textural and chemical compositions. In the following we describe the nephrites of these source areas in detail. (Table 1, Fig. 6 and Appendix 2) 
Possible nephrite sources in the Swiss Alps and in the Bohemian Massif

\begin{tabular}{|c|c|c|c|c|c|c|c|}
\hline $\begin{array}{l}\text { Number on } \\
\text { Figure } 6\end{array}$ & Location & $\begin{array}{l}\text { Description: } \\
\text { colour/fabric }\end{array}$ & GCD & FT & MAT & +Minerals & Ref \\
\hline \multicolumn{8}{|c|}{ Ct. Graubünden (Grisons) } \\
\hline 1 & Scortaseo & w, lgr (gr, bk) & + & $\mathrm{D}$ & $T$ & & $a, b$ \\
\hline 2 & Alpe d'Ur & $\mathrm{gr} / \mathrm{cf}$ & + & $\mathrm{S}$ & & & $\mathrm{a}, \mathrm{m}$ \\
\hline 3 & Piatte di Canciano & gygr, gr/fol, asb, fib & + & $\mathrm{S}$ & & & $a, j$ \\
\hline 4 & Cima Val Fontana & ND & & $\mathrm{D}$ & & & $a$ \\
\hline 5 & Fuorcla Fellaria & ND & & $S$ & A & & $a$ \\
\hline 6 & Furtschellas im Oberengadin & $\mathrm{dg} / \mathrm{cf}$ & + & $\mathrm{S}$ & A & & $\mathrm{a}, \mathrm{I}$ \\
\hline 7 & Lago di Cavlocc & ND & & & & & $\mathrm{a}$ \\
\hline 8 & Cuolms & dgr/cf & + & $\mathrm{S}$ & A & $\mathrm{mt}$ (isolated) & a \\
\hline 9 & Fuorcla da la Vallette & ND & & & & & a \\
\hline 10 & Fuorcla da Faller & bkgr/slat & & $S$ & & & a \\
\hline 11 & Muntognas digls Lajets & $\mathrm{dgr} / \mathrm{cf}$ & + & $\mathrm{S}$ & $\mathrm{A}$ & & $\mathrm{a}$ \\
\hline 12 & Ruine Marmorera & $\mathrm{gr} / \mathrm{cf}$ & & $\mathrm{S}$ & & & $\mathrm{a}$ \\
\hline 13 & Forschella-peak & $\begin{array}{c}\text { sogr to pgr/extremely fol, } \\
\text { lamellar jointing }\end{array}$ & + & $\mathrm{S}$ & A & $\begin{array}{c}\text { chl, mt, pic, } \\
\text { gt-g }\end{array}$ & $a, q, r$ \\
\hline 14 & Mühlen (Mulegns) & $\begin{array}{c}\text { 1: dgr/fol [parfib]; 2: Igr, } \\
\text { w/parfib [parfib]; 3: sogr to } \\
\text { pgr/extremely fol, lamellar } \\
\text { jointing }\end{array}$ & + & $S$ & A & $\begin{array}{l}\text { chl, mt, pic, } \\
\text { gt-g (ep, cc) }\end{array}$ & $a, b, q$ \\
\hline 15 & Sblocs & wgr / fol & & $\mathrm{S}$ & & & $\mathrm{a}$ \\
\hline 16 & Salux (Salouf) & dgr/cf, fol [parfib (very tough)] & + & $\mathrm{S}$ & & $\begin{array}{c}\text { gt-yg, pic, } \\
\text { chl, mt (iso- } \\
\text { lated } \\
\text { patches) }\end{array}$ & $q$ \\
\hline 17 & Piz Martegnas & ND & & $\mathrm{S}$ & & & $\mathrm{a}$ \\
\hline 18 & South of Crap Farreras & $\mathrm{dgr} / \mathrm{cf}$ & & $S$ & & $\begin{array}{l}\text { pure/carb, } \\
\text { sp, chl }\end{array}$ & a \\
\hline \multicolumn{8}{|c|}{ Other Swiss localities } \\
\hline 19 & Robenhausen (Pfäffikersee) & ND & + & $\mathrm{S}$ & & & $\mathrm{a}, \mathrm{e}$ \\
\hline 20 & Gotthardtunnel & ygr & + & $S$ & & & $a, e, k$ \\
\hline 21 & Gotthard & ND & + & $S$ & & & $a, e, k$ \\
\hline 22 & Andermat 25 & gygr & + & $S$ & A & & $a, k$ \\
\hline 23 & Haudères (Val d'Hérens) & gygr/cf & + & $S$ & & & $\mathrm{a}, \mathrm{h}$ \\
\hline 24 & $\begin{array}{l}\text { Neuenburgersee } \\
\text { (Lake Neuchâtel) }\end{array}$ & dgr-bk & + & $S$ & & & $\mathrm{a}, \mathrm{g}$ \\
\hline \multicolumn{8}{|c|}{ Boundaries of the Bohemian Massif } \\
\hline 25 & $\begin{array}{c}\text { Schwarzenbach an der Saale } \\
\text { (Frankenwald valley } \\
\text { in Bavaria, Germany) }\end{array}$ & $\mathrm{gr} / \mathrm{fib}$ & + & $S$ & A & $\underset{\mathrm{Ix}}{\mathrm{hbl}, \mathrm{chl}, \mathrm{mt}}$ & $q$ \\
\hline 26 & $\begin{array}{c}\text { Jordanów } \\
\text { (former Jordansmühl in } \\
\text { Schlesien) } \\
\text { (Polish Lower Silesia) }\end{array}$ & $\begin{array}{c}\text { w, grcr, bgr (lgr) to dgr (gybl,bl, } \\
\text { p)/cf or fol or sch [typ-nd, fib, } \\
\text { parfib] }\end{array}$ & + & $\mathrm{S}$ & $\mathrm{T}$ & \begin{tabular}{|c|} 
pure/pspx/di, \\
chl (com- \\
mon)/gr, \\
hgr, preh, \\
atg, Cr-sp, \\
tit, ap, mon, \\
zir \\
\end{tabular} & $\begin{array}{l}c, d, f, i \\
\text { n,o }\end{array}$ \\
\hline 27 & $\begin{array}{c}\text { Złoty Stok } \\
\text { (former Reichenstein in } \\
\text { Schlesien) } \\
\text { (Polish Lower Silesia) }\end{array}$ & $\begin{array}{l}\text { bgr (Igr) to dgr, gygr / cf or fib } \\
\text { or lay [typ-nd, fib, parfib] }\end{array}$ & + & $\mathrm{S}$ & $A(T)$ & $\begin{array}{l}\text { di, lö, mt, } \\
\text { carb, q, ap, } \\
\text { sche, serp, } \\
\text { aspy, gd }\end{array}$ & $c, d, p$ \\
\hline
\end{tabular}

Colour: bgr - bright green, bk - black, bkgr - blackish-greenish, bl - blue, dgr - dark green, gr - green, grcr - greenish-creamy, gybl - greyish-blue, gygr - greyish-green, lgr - light green, $\mathrm{p}$ - pink, pgr - pistachio-green, sogr - spring-onion green, ygr yellowish green, $w$ - white, wgr - whitish-green; macroscopic fabric: asb - asbestiform, cf - compact fabric, fib - fibrous, fol foliated, lay - layered, parfib - parallel fibrous, slat - slatey, sch - schistose; [microscopic fabric]: fib - fibrous, parfib - parallel fibrous, typ-nd - typical non-directional; ND - more detailed descriptions/data not available; GCD - geochemical data available; FT - formation type: D - dolomite-related deposits (D-type), S - serpentinite-related deposits (S-type); MAT - main amphibole type: A - actinolite, T - tremolite; +Minerals - associated and enclosed minerals: ap - apatite, aspy - arsenopyrite, atg antigorite, carb - carbonate, cc - calcite, chl - chlorite, Cr-sp - Cr-spinel, di - diopside, ep - epidote, gd - gold, gr - grossular, gt-g - green Ca-Al-garnet, gt-yg - yellowish-green garnet, hbl - hornblende, hgr - hydrogrossular, lö - löllingite, Ix - leucoxene, mon - monazite, $\mathrm{mt}$ - magnetite, pic - picotite, preh - prehnite, pspx - pseudomorphs after pyroxene, pure - pure nephrite, $q$ quartz, sche - scheelite, serp - unspecified serpentine, sp - spinel, tit - titanite, zir - zircon; Ref - references: a - Dietrich and de Quervain (1968); b - Giess (2003); c - Gil (2013); d - Gunia (2000); e - Heierli (1902); f - Mazur et al. (2006); g - Meyer (1884); h - Preiswerk (1926); i - Sachs (1902); j - Schmidt (1917); k - Schneider (1912); I Staub (1915); m - Staub (1917); n - Traube (1885a); o - Traube (1885b); p - Traube (1887); q - Welter (1911a); $r$ - Welter (1911b); for more detailed descriptions see Appendix 2 

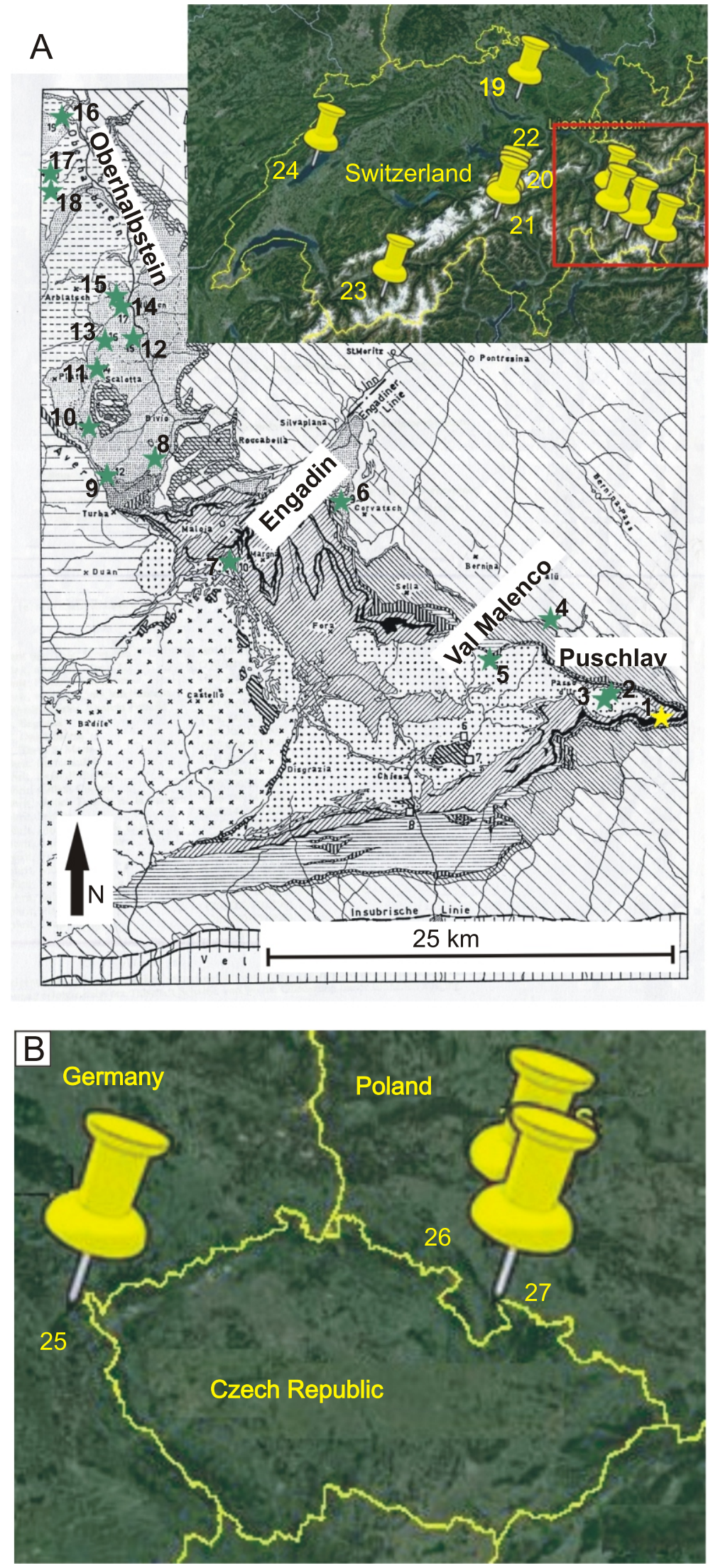

RESULTS OF PETROCHEMICAL AND MINERAL-CHEMICAL ANALYSES

Results of the bulk chemical (and EPMA) analyses of the Baden Culture nephrite adze from Balatonőszöd - Temetői dülö site have been compared with published data for known nephrite occurrences. Results of new PGAA-measurements of recently found nephrite samples from Jordanów and Złoty Stok (Fig. 7 and Appendix 1) have also been used.

Binary diagrams have been constructed: diagrams illustrating magnesium and iron contents plotted against silicon contents are shown here (Figs. 8 and 9).

[For brief descriptions of nephrite samples, see the texts in square brackets in Appendix 2]

The chemical composition of rock-forming amphiboles from the Jordanów and Złoty Stok deposits (Gil, 2013) have been compared with that of the nephrite adze (Fig. 4).

\section{EVALUATION OF THE RESULTS AND THE MOST PROBABLE PROVENANCE}

On the basis of macroscopic appearance, mineral composition and fabric character (considering the possible sources described above), sources of nephrite notably similar to the raw material of the Balatonőszöd - Temetői dülő nephrite adze are: Jordanów, Złoty Stok and Cuolms (though the last of these has insufficiently detailed description).

Chemically the most similar nephrites to the Balatonőszöd - Temetői dülő nephrite adze occur at Salux and Piatte di Canciano, while very similar nephrites also can be found around the boundaries of the Bohemian Massif (Jordanów, Złoty Stok,

Fig. 6A-map (Dietrich and Quervain, 1968), modified to show nephrite occurrences in the Swiss Alps; B map, modified to show nephrite occurrences at the boundaries of the Bohemian Massif

1 - Scortaseo, 2 - Alpe d'Ur, 3 - Piatte di Canciano, 4 Cima Val Fontana, 5 - Fuorcla Fellaria, 6 - Furtschellas im Oberengadin, 7 - Lago di Cavlocc, 8 - Cuolms, 9 Fuorcla da la Vallette, 10 - Fuorcla da Faller, 11 Muntognas digls Lajets, 12 - Ruine Marmorera, 13 Forschella-peak, 14 - Mühlen (Mulegns), 15 - Sblocs, 16 - Salux (Salouf), 17 - Piz Martegnas, 18 - Crap Farreras, 19 - Robenhausen (Pfäffikersee), 20 Gotthardtunnel, 21 - Gotthard, 22 - Andermatt, 23 Haudères, 24 - Neuenburgersee (Lake Neuchâtel), 25 Schwarzenbach an der Saale, 26 - Jordanów, 27 - Złoty Stok 

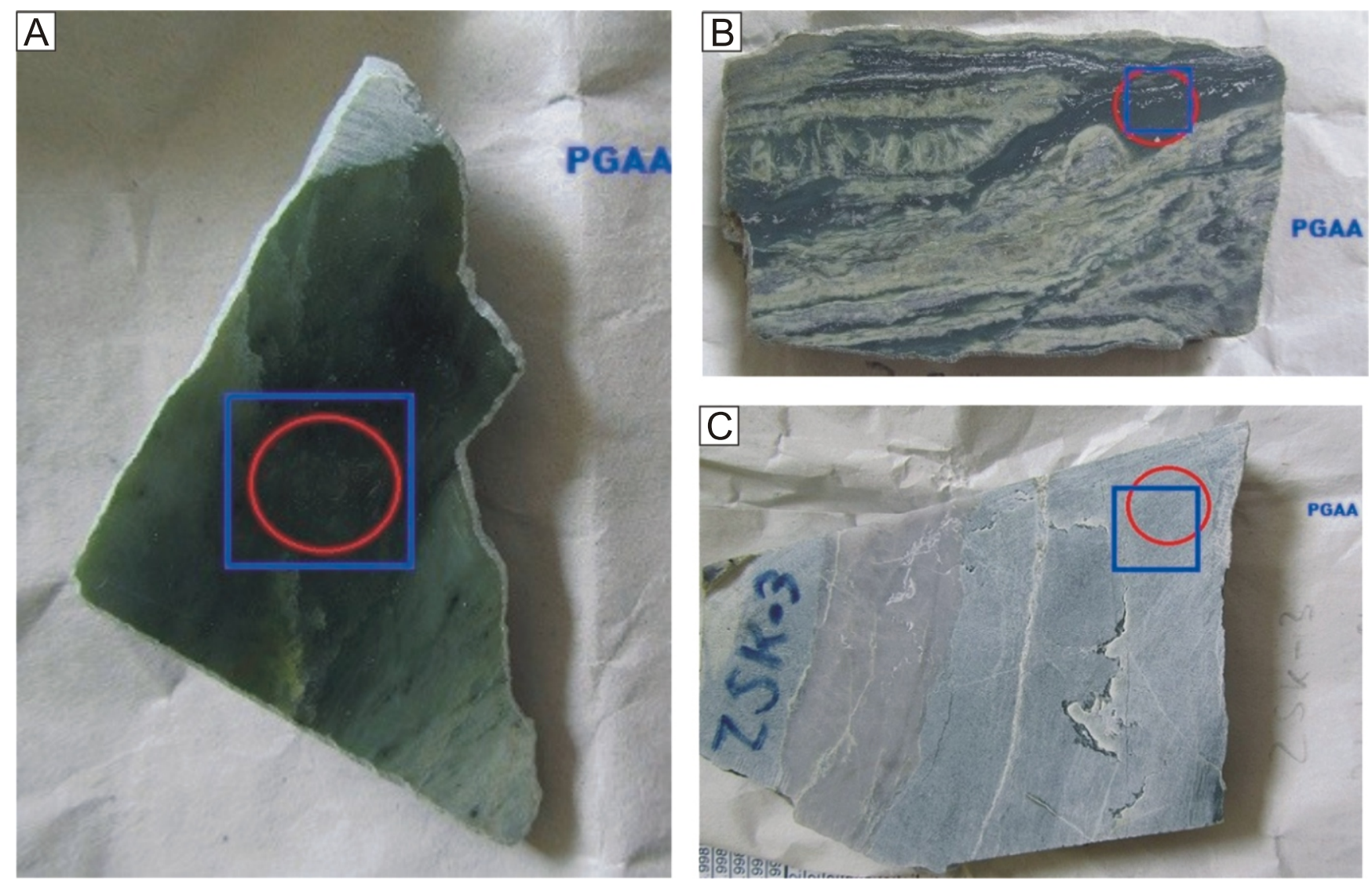

Fig. 7. Photos of nephrite samples from Jordanów (A) and Złoty Stok (B, C) nephrite deposits in Poland, with the area measured by PGAA

Blue squares - size of the measured area: $2 \times 2 \mathrm{~cm}$

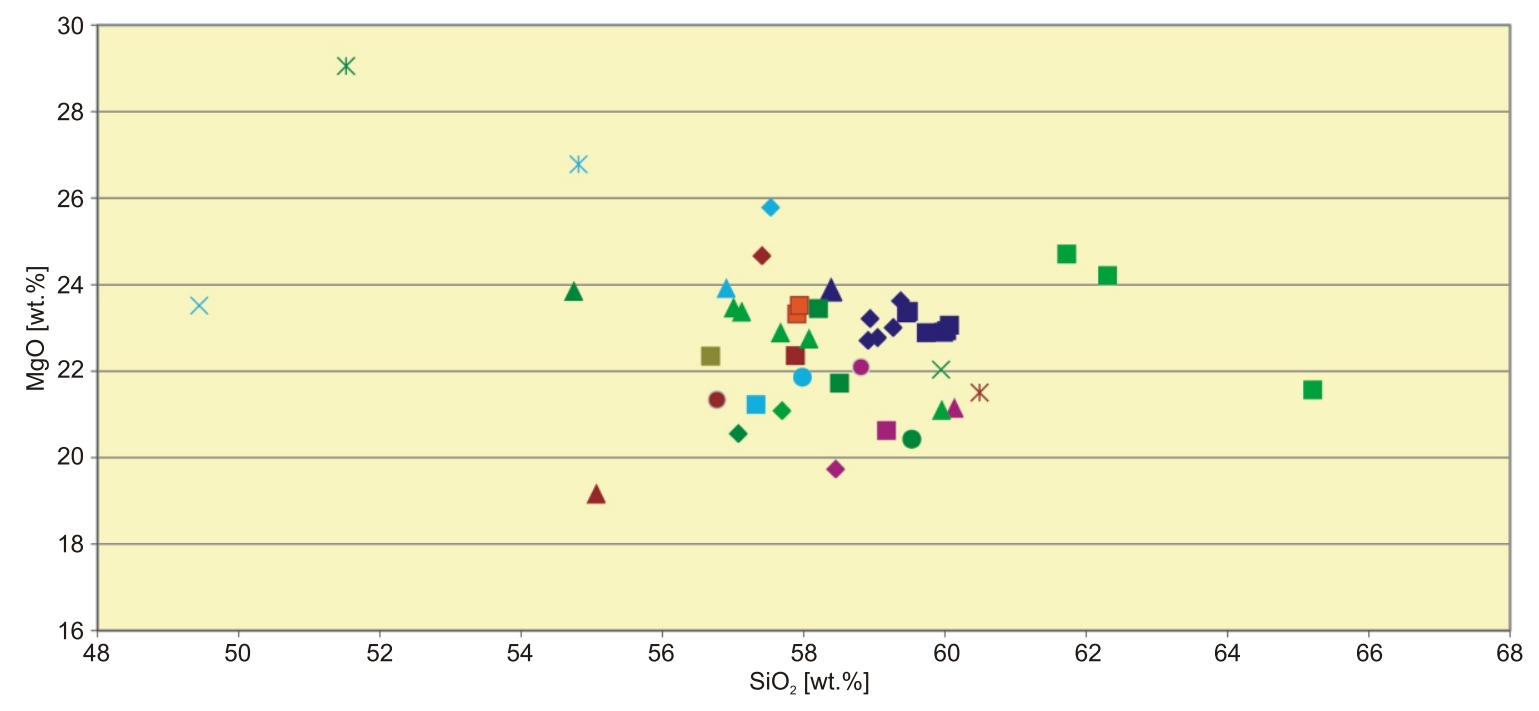

Fig. 8. Bulk-rock chemistry of the nephrite adze and nephrite samples from various geological sites: $\mathrm{MgO}$-content (wt.\%) as a function of $\mathrm{SiO}_{2}$-content (wt.\%) with EPMA-results from the adze

Explanations as in Figure 5 


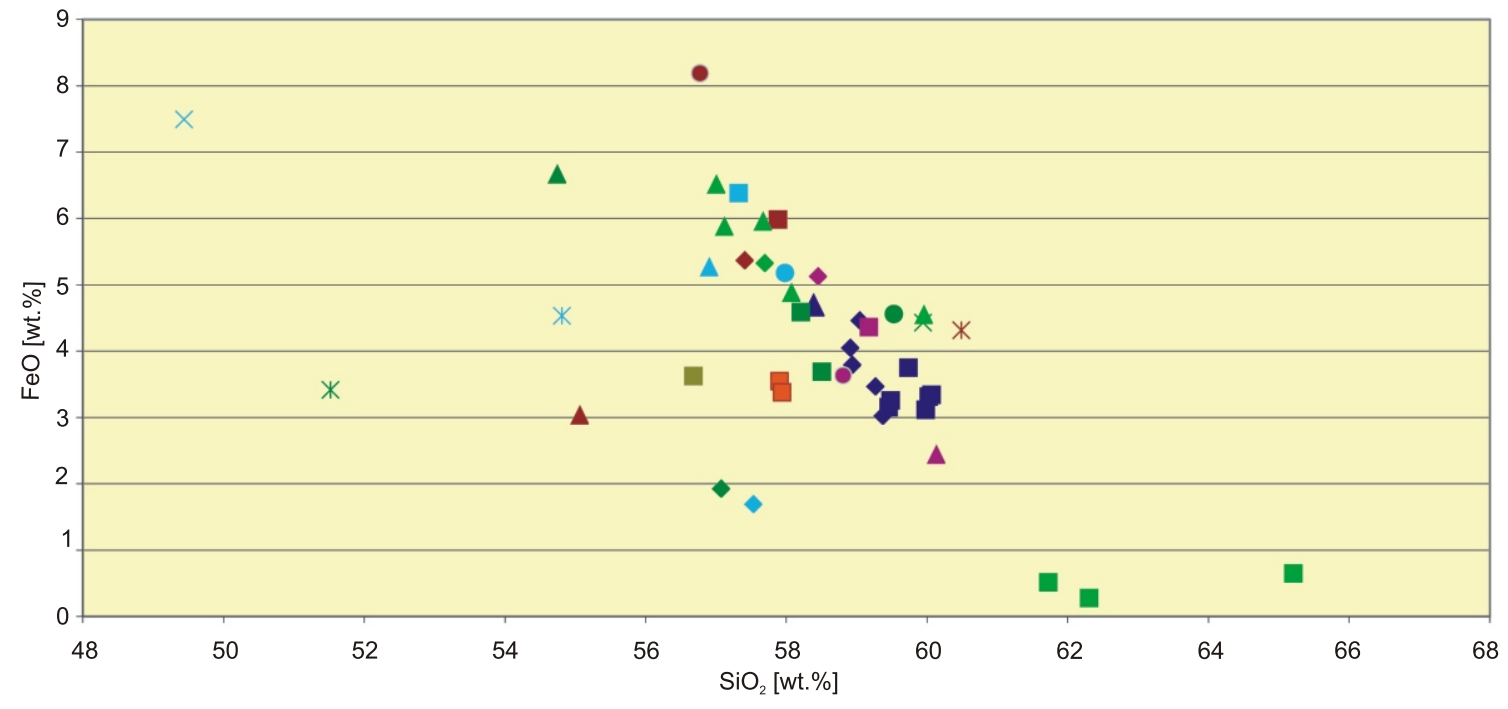

Fig. 9. Bulk-rock chemistry of the nephrite adze and nephrite samples from various geological sites: $\mathrm{FeO}(\mathrm{t})$-content (wt.\%) as a function of $\mathrm{SiO}_{2}$-content (wt.\%); with EPMA-results from the adze

Explanations as in Figure 5

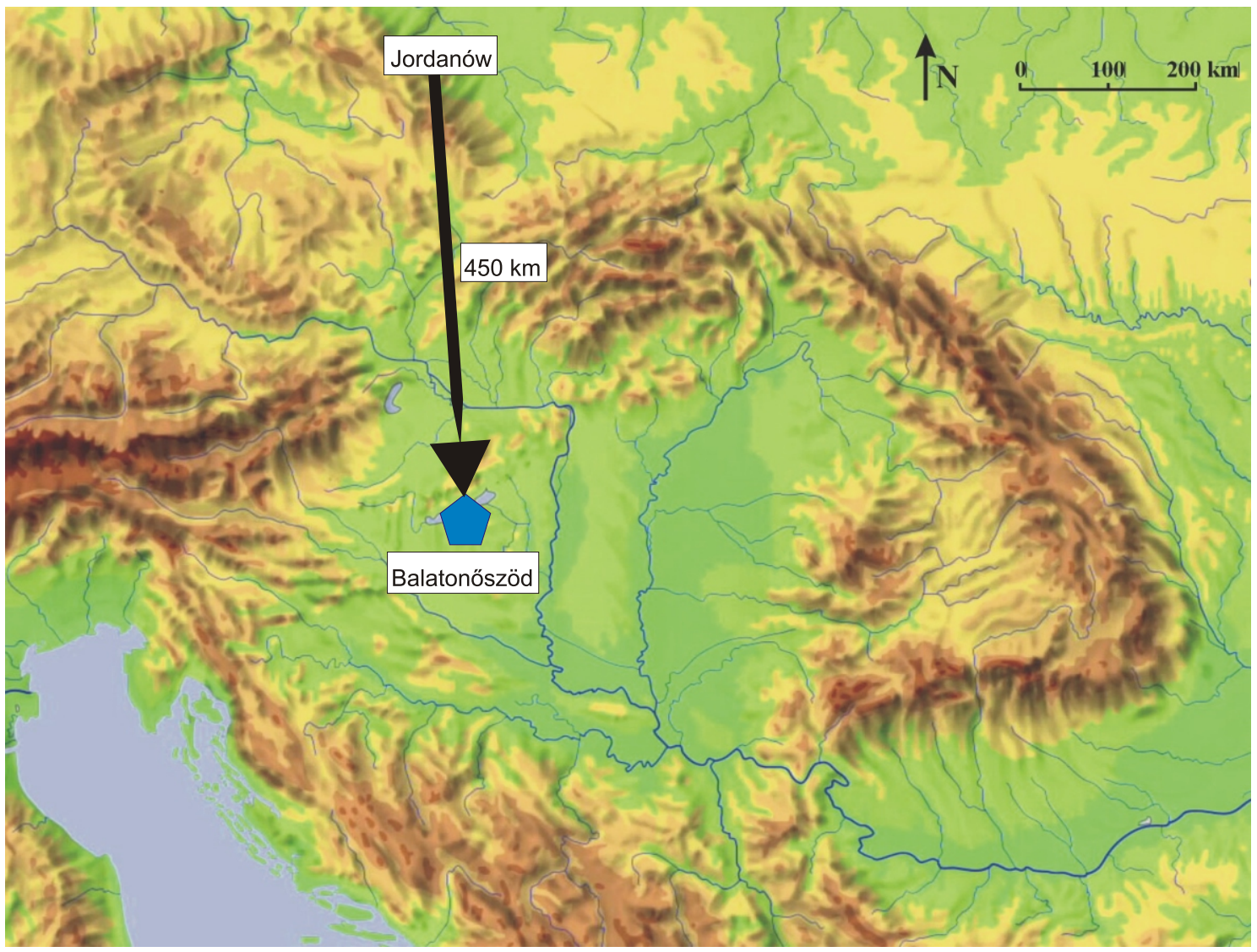

Fig. 10. Map (Zentai, 1996), modified to show the archaeological site and the most probable source of origin of the nephrite raw material of the adze examined 
Schwarzenbach an der Saale) and from Cuolms, Muntognas, Alpe d'Ur and Neuenburgersee.

The following sources of raw material may likely be excluded: Salux - due to the different enclosed minerals (garnet, spinel, chlorite); Piatte di Canciano - because of its schistosity and being asbestose; Schwarzenbach an der Saale - because of its typical "actinolite structure" and the presence of hornblende; Złoty Stok - due to the different enclosed minerals (löllingite, apatite, scheelite, arsenopyrite); Cuolms, Muntognas, Alpe d'Ur and Neuenburgersee - since the descriptions are insufficiently detailed - may be excluded only on the basis of colour.

To sum up: on the basis of macroscopic appearance, mineral composition, fabric character and the bulk chemical composition the most probable raw material sources are Jordanów and Cuolms.

Although we have mineral-chemical data only from two geological sites (Jordanów and Złoty Stok), all data from the EPMA-analyses of the nephrite adze are similar to nephrite from Jordanów.

Stone axes made of Jordanów nephrite have been found about $15 \mathrm{~km}$ north of Jordanów (Neolithic); in the central part of Poland (near Gniezno; Danubian Culture); and also in Upper Silesia (Funnel Beaker Culture, Corded Ware Culture; Foltyn et al., 2000; Gunia, 2000) and probably from a Late Neolithic Silesian site (Prichystal et al., 2012). The Boleraz Culture in Moravia developed from one of the Funnel Beaker Culture groups, supposedly by mingling. Contemporaneous with the Corded Ware Culture - that developed from the Funnel Beaker Culture - was Baden Culture, a fortified settlement of which was excavated near the above-mentioned provenances of Corded Ware Culture in the Moravian Gateway - a system of narrow depressions between the Bohemian Massif and the Carpathians - that provides a main cross-connection between the northern plain territories of Middle Europe and the Carpathian Basin (Prichystal, 2000). Therefore, connection must have existed between the Baden Culture and the nephrite-sources of the Jordanów district, whereas the Cuolms provenance in the Swiss Alps (and the "Mur Nockerls" as a nearer source) could have been reached only in the Boleráz era and via circum-alpine interrelations (as the nearer source, the "Mur Nockerls").

Serpentinites containing nephrite-bodies - cropping out on the northern boundaries of gneisses of the Góry Sowie Massif were used to make stone-axes in the Neolithic Age, as were the serpentinites cropping out on the eastern and southern boundaries of the Góry Sowie Massif (Majerowicz et al., 2000; Skoczylas et al., 2000). It has been shown that local serpentin- ite was excavated (Wojciechowski, 1995) and polished stone tools made of them were dispersed as widely as $340 \mathrm{kms}$ away (Skoczylas et al., 2000). In the time of the Corded Ware Culture, there was a centre for extracting and processing serpentinite in this territory; its most important products were the so-called "Ślęża-type" shaft-hole axes (Skoczylas et al., 2000).

\section{SUMMARY}

The present study provides petrographic and geochemical analyses of a Late Copper Age (Baden Culture) nephrite adze from the archaeological site at Balatonőszöd - Temetői dűlő. This adze is the single nephrite stone artefact so far found at this site.

Nephrite present in archaeological finds in Hungary is rare and known exclusively from Transdanubian sites, but without identification according to either age or culture. Therefore, the Balatonőszöd - Temetöi dülö nephrite adze is the first find that has a reliable archaeological context dating back to Hungarian prehistory.

By applying detailed petrographic, geochemical and petrophysical methods as well as comparison with published data, we have located the origin of the raw material of the nephrite adze studied. On the basis of its macroscopic appearance, mineral composition, fabric character, bulk chemical composition, magnetic features, the contemporaneous raw material extraction and the cultural relations in the era of the Baden Culture, the most probable location of the raw material of the nephrite adze studied is the geological site at Jordanów (northern part of the Bohemian Massif, Lower Silesia, Poland; Fig. 10).

Acknowledgements. We are indebted to T. Horváth, leading archaeologist of the excavations at Balatonőszöd - Temetői dúlő archaeological site, for affording us the opportunity to study the stone tools excavated. We are especially grateful to Á. Veres for deciphering the complicated text of the 19th century German literature. We want particularly to thank E.P. Szabó, K.T. Biró and J. Zalasiewicz for helping to render the text of our study into English. T.M. Peryt is appreciated for editorial corrections. We are thankful to A. Prichystal, D. Hovorka and Anonymous for revision and constructive comments that improved this paper. Special thanks go to the Hungarian Scientific Research Fund OTKA Grant No. K 62874 and K 100385 for their financial support. The PGAA experimental station has been developed with the support of the "NAP VENEUS05" project, Nr. OMFB 00184/2006.

\section{REFERENCES}

Bendő Zs., Oláh I., Péterdi B., Horváth E. (2012) Case studies on a non-destructive SEM-EDX analytical method for polished stone tools and gems. In: 39th International Symposium on Archaeometry (eds. D. Braekmans, J. Honings and P. Degryse): 136. Leuven.

Bradák B., Szakmány Gy., Józsa S. (2005) Mágneses szuszceptibilitás mérések - új módszer alkalmazása csiszolt kőeszközök vizsgálatában. Archeometriai Mühely/ Archaeometry Workshop (www.ace.hu/am), 2005 (1): 13-22.

Bradák B., Szakmány Gy., Józsa S., Přichystal A. (2009) Application of magnetic susceptibility on polished stone tools from Western Hungary and the Eastern part of the Czech Republic (Central Europe). Journal of Archaeological Science, 36: 2437-2444. 
D’Amico C., Starnini E., Gasparotto G., Ghedini M. (2003) Eclogites, jades and other HP-metaophiolites employed for prehistoric polished stone implements in Italy and Europe Periodico di Mineralogia, 73: 17-42.

Dietrich V., Quervain F., de (1968) Die Nephrit-Talklagerstätte Scortaseo (Puschlav, Kanton Graubünden). Übersicht der Weiteren Nephritfunde der Schweizer Alpen Insbesondere der Vorkommen im Oberhalbstein (Graubünden). Beiträge zur Geologie der Schweiz, Geotechnische Serie, 46.

Foltyn E.M., Foltyn E., Jochemczyk L., Skoczylas J. (2000) Basalte und Nephrite im Neolithikum Mittel-Westpolens und der oberschlesieschen Region. Krystalinikum, 26: 67-81.

Friedel O. (2008) Az Ebenhöch csiszolt kőeszköz gyűjtemény archeometriai vizsgálatának eredményei. Msc Thesis (unpublished). Eötvös Loránd University, Department of Petrology and Geochemistry, Budapest.

Friedel O., Bradák B., Szakmány Gy., Szilágyi V., Biró K.T. (2008) Összefoglaló az Ebenhöch csiszolt kőeszköz gyűjtemény archeometriai vizsgálatának eredményeiről. Archeometriai Műhely/Archaeometry Workshop (www.ace.hu/am), 2008: $1-12$.

Giess H. (2003) Jade in Switzerland - April 2003. Friends of Jade. www.friendsofjade.org

Giess H. (2005) Mur Nockerln - Austrian Dumplings in Nephrite Jade! Friends of Jade. www.friendsofjade.org

Gil G. (2013) Petrographic and microprobe study of nephrites from Lower Silesia (SW Poland). Geological Quarterly, 57 (3): 395-404.

Gunia P. (2000) Nephrite from South-Western Poland as potential raw material of the European Neolithic artefacts. Krystalinikum, 26: 167-171.

Heierli J. (1902) Die Nephritfrage mit spezieller Berücksichtigung der schweizerischen Funde. Anzeiger für Schweizerische Altertumskunde, 1: 1-7.

Horváth T. (2001) Polished stone tools of the Miháldy-collection, Laczkó Dezső Museum, Veszprém. (Archaeological investigation). In: Sites and stones. Lengyel Culture in Western Hungary and beyond. A review of the current research. Lengyel'99 and IGCP-442 Conference Veszprém, 1999 (ed. J. Regenye): 87-109. Directorate of the Veszprém county Museums, Veszprém.

Horváth T. (2010) Megfigyelések a középső és késő rézkori kultúrák fazekasáruin Balatonőszöd-Temetői dűlő lelőhelyen. Készítéstechnikai vizsgálatok. Archeometriai Mühely/ Archaeometry Workshop (www.ace.hu/am), 2010: 51-82.

Horváth T., S. Svingor É., Molnár M. (2006) Újabb adatok a Baden-péceli kultúra keltezéséhez. Archeometriai Mühely/ Archaeometry Workshop (www.ace.hu/am), 2006: 19-30.

Kalkowsky E. (1906) Der Nephrit des Bodensees. Abhandlungen der Naturwissenschaftlichen Gesellschaft "Isis" in Dresden, 1 28-44.

Kostov R.I. (2005) Gemmological significance of the prehistoric Balkan "Nephrite Culture" (cases from Bulgaria). Annual of the University of Mining and Geology "St. Ivan Rilski", Part I, Geology and Geophysics, 48: 91-94.

Leake B.E., Woolley A.R., Arps C.E.S., Birch W.D., Gilbert C.M., Grice J.D., Hawthorne F.C., Kato A., Kisch H.J., Krivovichev V.G., Linthout K., Laird J., Mandarino J.A., Maresch W.V., Nickel E.H., Rock N.M.S., Schumacher J.C., Smith D.C. Stephenson N.C.N., Ungaretti L., Whittaker E.J.W., Youzhi G. (1997) Nomenclature of amphiboles: report of the subcommittee on amphiboles of the International Mineralogical Association, commission on new minerals and mineral names. Canadian Mineralogist, 35: 219-246.

Mazur S., Aleksandrowski P., Kryza R., Oberc-Dziedzic T. (2006) The Variscan orogen in Poland. Geological Quarterly, 50 (1): 89-118.
Majerowicz A., Wojcik A., Gunia P., Cholewa P. (2000) Comparative study of serpentinite textures and rock material of Neolithic artefacts from Lower Silesia (SW Poland). Krystalinikum, 26: 111-117.

Meyer A.B. (1884) Ein weiterer Beitrag zur „Nephritfrage”. Mitteilungen der Anthropologischen Gesellschaft in Wien, 15: $1-12$.

Péterdi B., Szakmány Gy., Judik K., Dobosi G., Kovács J., Kasztovszky Zs., Szilágyi V. (2011) Bazalt anyagú csiszolt kőeszközök kőzettani és geokémiai vizsgálata (Balatonőszöd Temetői Dűlő lelőhely). Archeometriai Műhely/Archaeometry Workshop (www.ace.hu/am), 2011: 33-68.

Preiswerk H. (1926) Nephrit von Haudères (Wallis), Schweiz. Mineralogische und Petrographische Mitteilungen, 6: 267-277.

Prichystal A. (2000) Stone raw materials of Neolithic-Aeneolithic polished artefacts in the Czech Republic: the present state of knowledge. Krystalinikum, 26: 119-136.

Přichystal A., Kovář J.J., Kuča M. (2012) A nephrite axe from the Jeseník Museum. Časopis Slezského Zemského Muzea, Série B, 60: 153-159.

Révay Zs. (2009) Determining elemental composition using prompt gamma activation analysis. Analytical Chemistry, 81: 6851-6859.

Sachs A. (1902) Der „Weissstein” des Jordansmühler Nephritvorkommens. Centralblatt für Mineralogie, Geologie und Palaeontologie: 385-396.

Schmidt C. (1917) Asbest und Nephrit von Poschiavo in Graubünden. Zeitschrift für praktische Geologie: 77-81.

Schneider A. (1912) Der Diallag-Peridotit und seine Umwandlungsprodukte auf Gigestaffel südlich Andermatt. Diss. Univ. Zürich: 7-68.

Skoczylas J., Jochemczyk L., Foltyn, E., Foltyn, E. (2000) Neolithic serpentinite tools of west-central Poland and Upper Silesia. Krystalinikum, 26: 157-166.

Staub R. (1915) Petrographische Untersuchungen im westlichen Berninagebirge. Vierteljahrsschrift der Naturforschenden Gesellschaft in Zürich, 60: 55-336.

Staub R. (1917) Bericht über die Exkursion der Schweiz. Geologischen Gesellschaft. Eclogae Geologicae Helvetiae, 14.

Szakmány Gy., Kasztovszky Zs. (2004) Prompt Gamma Activation Analysis: a new method in the archaeological study of polished stone tools and their raw materials. European Journal of Mineralogy, 16: 285-295.

Szakmány Gy., Füri J., Szolgay Zs. (2001) Outlined petrographic results of the raw materials of polished stone tools of the Miháldy-collection, Laczkó Dezső Museum, Veszprém (Hungary). In: Sites and stones. Lengyel Culture in Western Hungary and beyond. A review of the current research. Lengyel'99 and IGCP-442 Conference Veszprém, 1999 (ed. J. Regenye): 109-118. Directorate of the Veszprém county Museums, Veszprém.

Szakmány Gy., Kasztovszky Zs., Szilágyi V., Starnini E., Friedel O., Biró K.T. (2011) Discrimination of prehistoric polished stone tools from Hungary with non-destructive chemical Prompt Gamma Activation analyses (PGAA). European Journal of Mineralogy, 23: 883-893.

Szentmiklósi L., Belgya T., Révay Zs., Kis Z. (2010) Upgrade of the prompt gamma activation analysis and the neutron-induced prompt gamma spectroscopy facilities at the Budapest Research Reactor. Journal of Radioanalytical and Nuclear Chemistry, 286: 501-505.

Traube H. (1885a) Ueber den Nephrit von Jordansmühl in Schlesien. Neues Jahrbuch für Mineralogie, Geologie und Palaeontologie (Beilage-Band), 3: 412-427.

Traube H. (1885b) Über den Nephrit von Jordansmühl in Schlesien. Neues Jahrbuch für Mineralogie, Geologie und Palaeontologie, (II. Band): 91-94. 
Traube H. (1887) Ueber einen neuen Fund von anstehendem Nephrit bei Reichenstein in Schlesien. Neues Jahrbuch für Mineralogie, Geologie und Palaeontologie, (II. Band): 275-278.

Welter O.A. (1911a) Ein Beitrag zur Geologie des Nephrits in den Alpen und im Frankenwalde. Neues Jahrbuch für Mineralogie, Geologie und Paläontologie, (II. Band): 86-106.

Welter O.A. (1911b) Nachtrag zu meinem Aufsatz über Nephrit (dies. Jahrb. 1911. II). Neues Jahrbuch für Mineralogie, Geologie und Paläontologie, (II. Band): 163.
Wojciechowski W. (1995) Die neolitische Serpentinit Mine vom Jańska Góra in Niederschlesien, Polen. Veröffentlichungen des Brandenburgischen Landesmuseums für Ur- und Frühgeschichte, 29: 201-208.

Zentai L. (1996) Geographic map. http://lazarus.elte.hu/hun/summer.jpg.

Zhang Z.W., Gan F.X., Cheng H.S. (2011) PIXE analysis of nephrite minerals from different deposits. Nuclear Instruments and Methods in Physics Research B, 269: 460-465. 